\title{
The Boundaries of Credit Insurance: A Comment
}

\author{
by Jan W. Hoobroeckx*
}

Credit insurance covers the risk of a firm (insured) failing to receive payment for goods supplied or services rendered.

The insurance may cover one transaction only - generally in the case of major supplies of a one of a kind nature, e.g. capital goods or contracts for works - or the insured's entire turnover, or parts thereof, e.g. all home sales, all exports, or exports to certain countries.

The insurance covers the customary instalments of credit. The insurer indicates in respect of each customer to what amount (or limit) the insured's risk is covered. The total limits held covered for a customer are called the "liability".

Important is the distinction between the "commercial" and the "political" risk. The "commercial" risk is that which rests with the customer, i.e. his solvency, or otherwise lack of means. The "political" risk is that associated with the customer's country. It also includes default by a government purchaser.

\section{Limitations inherent in the system of credit insurance}

An important cornerstone of insurance generally is to spread the risk and to do so in sufficient quantities. The credit insurer must pay this aspect special attention since an insuree is less likely to seek insurance on payments which he feels certain of getting. It is moreover a special feature of credit insurance that the subjectmatter is sensitive to prevailing economic trends. It may be inferred from this that in bad times insurance will encounter a large proportion of bad risks, and thus a lot of claims. The credit insurer must therefore be particularly attentive to spreading the risk.

Every insurer lodges part of his interest - of the risk which he runs - with others who are then in the position of reinsurers. The limits which the reinsurer places on his willingness to accept risks also clearly define the limits for the direct insurer.

The number of countries is limited and as regards the risk of an entire country being unable to pay its debts it is clear that the spread of risk so necessary to the insurer is quite a problem. It has been long assumed generally that the problem is too great for private

\footnotetext{
* President of the Berne Union, President of Netherlands Credit Insurance Company, Amsterdam.
} 
undertakings, whether insurers or reinsurers, and this is why the State has assumed the political risk, in the form of reinsurance or as a direct insurer, in all exporting countries where credit insurers operate.

All insurers and thus also credit insurers everywhere will make every effort to keep their risk capital, including free reserves, at a sound level, to say nothing of their underwriting reserves.

\section{Limitations inherent in the nature of the risk}

Like the banks, the insurer when assessing the risk will go by the information in the debtor's balance sheet and profit and loss account.

Between the stage where the customer may be considered good for the supplier credit he requires for his business and the stage where a customer can no longer discharge his obligations towards suppliers lies a large area.

Credit insurance provides the supplier with a considerable boost in his ability to use his capital for more business. He is always obliged to carry a certain amount (a fixed percentage or otherwise) of the payment risk as his own. At a certain level he has to ask himself whether he can bear that risk notwithstanding that the larger part is covered by insurance. This point is more readily reached in medium term transactions because the outstanding credit accumulates and this can lead to reluctance to further financing by the supplier's bankers.

\section{Financial difficulties of countries}

An important principle adopted by the credit insurer when assessing political risks (as well as commercial risks) is that these must be sound at the time of acceptance. This means that the method of assessing the country lays stress on analysis of the existing situation and an analysis of past progress so as to understand the origins of the present situation.

A private credit insurer has to consider political risk even if he only underwrites commercial risks, because the economic and political circumstances in which the private buyers have to execute their business may influence their creditworthiness.

Because it depends to a large extent on political events - civil war, social unrest, and the like, and also on the nature of the economic policies and on economic circumstances which may change at short notice - the international risk is nearly always unforecastable by definition. 